\title{
CORPORATE GOVERNANCE SEBAGAI VARIABEL MODERATING DENGAN NET WORKING CAPITAL, CAPITAL EXPENDITURE, CASH CONVERSION CYCLE, CASH FLOW, DAN GROWTH OPPORTUNITY YANG DAPAT MEMPENGARUHI CASH HOLDING
}

\author{
Nur Hayati \\ Universitas Semarang \\ Email korespondensi : nhayyati4@gmail.com \\ Received: 25 Aug $2020 \quad$ Reviewed: 2 Sept $2020 \quad$ Accepted: 2 Oct $2020 \quad$ Published:30 Oct 2020

\begin{abstract}
This research is intended to analyze net working capital, capital expenditure, cash conversion cycle, cash flow and growth opportunity towards cash holding with the activity of the board of commissioners as a moderating variable. The population of this research is all consumer goods industry companies listed on the Indonesia Stock Exchange in 2014-2018. The sample of this research is 30 companies determined by purposive sampling technique. The data analysis technique used in this study is multiple linear regression analysis using WarpPLS 6.0 software. The results show that net working capital, capital expenditure dan growth opportunity have no signifikan relationship on cash holding. Meanwhile, cash conversion cycle and cash flow have significant relationship on cash holding. The result of shows that the activity of the board of commissioners can moderate between cash conversion cycle and cash flow on cash holding. It is suggested that future studies use other models, apart from multiple linear regression and increase the sample of companies.
\end{abstract}

Keywords: Net Working Capital, Capital Expenditure, Cash Conversion Cycle, Cash Flow, Growth Opportunity

\begin{abstract}
ABSTRAK
Penelitian ini bertujuan untuk menganalisis net working capital, capital expenditure, cash conversion cycle, cash flow dan growth opportunity terhadap cash holding dengan aktivitas dewan komisaris sebagai variabel moderating. Populasi penelitian ini seluruh perusahaan industri barang konsumsi yang terdaftar pada Bursa Efek Indonesia periode 2014-2018. Sampel penelitian ini sebanyak 30 perusahaan yang diambil dengan teknik purposive sampling. Teknik analisis data yang digunakan pada penelitian ini adalah analisis regresi linear berganda dengan menggunakan software WarpPLS 6.0. Hasil analisis menunjukkan bahwa variabel net working capital, capital expenditure dan growth opportunity tidak berpengaruh signifikan terhadap cash holding. Sedangkan, variabel cash conversion cycle dan cash flow berpengaruh signifikan terhadap cash holding. Hasil penelitian juga menunjukkan aktivitas dewan komisaris dapat memoderasi variabel cash conversion cycle dan cash flow terhadap cash holding. Disarankan penelitian yang akan datang menggunakan model lain, selain regresi linear berganda dan menambah sampel.
\end{abstract}

Kata kunci: Net Working Capital, Capital Expenditure, Cash Conversion Cycle, Cash Flow, Growth Opportunity 


\section{A. PENDAHULUAN}

Kas merupakan kebutuhan yang digunakan perusahaan untuk membiayai kegiatan operasional yang sifatnya secara rutin serta intermittent. Biaya rutin yang dikeluarkan perusahaan dari kas yaitu membeli bahan baku, membayar upah dan gaji karyawan, membayar beban listrik, internet, telepon, dan beban lainnya. Sedangkan, untuk pembiayaan intermitten misalnya untuk melakukan investasi, membayar hutang, membayar dividen, pembelian asset tetap dan lainnya. Kas dapat dikatakan sebagai peran penting dalam perusahaan. Jika terjadi kesalahan dalam melakukan perhitungan dan perkiraan kas keluar maka dapat berakibat pailitnya perusahaan. Hal ini mengakibatkan perusahaan perlu melakukan manajemen kas yang baik serta diimplementasikan kebijakan terhadap cash holdings. Perusahaan industri barang konsumsi merupakan salah satu dari perusahaan manufaktur yang ada di Indonesia. Perusahaan tersebut terdiri dari berbagai sub sektor dan masih menjadi pilihan utama bagi para investor dalam menginvestasikan dananya. Hal ini terjadi karena pada perusahaan barang konsumsi memiliki prospek baik dan pangsa pasar yang luas serta produk yang dihasilkan merupakan produk untuk kebutuhan sehari-hari. Berikut ditampilkan gambar 1 yang menunjukkan rasio cash holding perusahaan consumer goods.

Gambar 1. Rasio Cash Holding Consumer Goods tahun 2014-2018

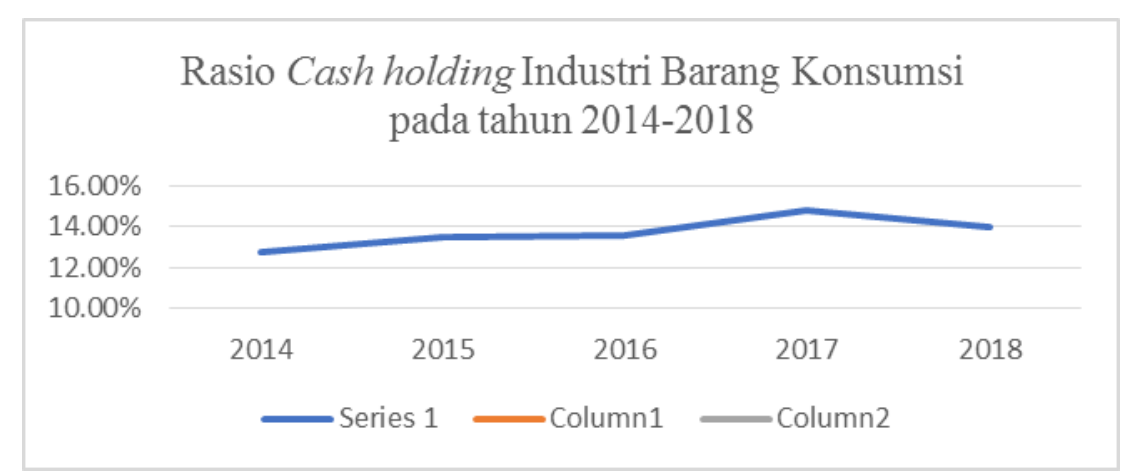

Sumber: www.idx.co.id (2019)

Rasio cash holdings pada perusahaan consumer goods memiliki nilai rasio yang berbeda dari tahun 2014-2018 yaitu nilai rata-rata rasio sebesar 12,75\% - 14,75\%. Sedangkan dari hasil penelitian yang telah ada menunjukkan bahwa rasio cash holding di masing-masing negara berbeda. Rasio cash holding merupakan perbandingan antara kas dan setara kas dengan hasil total aset. Menurut penelitian (Mesfin, 2016) rasio cash holding di Ethiopia 
berada pada kisaran 8,6\%. Rasio cash holding di India berada pada kisaran 5,7\% (Das, 2017). Sedangkan menurut (Romadhoni, Kufepaksi, \& Hendrawaty, 2019) perkembangan rasio cash holding di perusahaan publik non keuangan di Indonesia selama tahun 2000-2011 berada pada kisaran 9,8\%-13,1\%. Nilai rata-rata cash holding di Indonesia tergolong memiliki rasio yang cukup tinggi jika dibandingan dengan negara lain. Hal ini dapat diartikan perusahaan yang ada di Indonesia khususnya sektor industri barang konsumsi cenderung lebih besar untuk menahan kas dibandingkan melakukan investasi. Oleh karena itu, perlunya perusahaan untuk melakukan manajemen kas yang baik serta diimplementasikan dalam kebijakan terhadap cash holding.

Penelitian cash holding menjadi hal yang menarik untuk diteliti, sehingga banyak penelitian-penelitian yang sudah dilakukan dengan hasil yang berbeda. Penelitian yang dilakukan Maarif, Anwar, \& Darmansyah (2019) berpendapat bahwa net working capital terhadap cash holding tidak signifikan, sedangkan hasil penelitian Wulandari \& Setiawan (2019) dan William \& Fauzi (2013) berpengaruh signifikan dan positif. Penelitian yang dilakukan oleh Ariana, Hadjaat, \& Yudaruddin (2018) dan Maarif, Anwar, \& Darmansyah, (2019) dengan hasil capital expenditure bernilai positif, namun tidak signifikan terhadap cash holding. Sedangkan menurut penelitian Yanti, Susanto, Wirianta, \& Viriany, Maret (2019) hasilnya berpengaruh signifikan dan bernilai negatif.

Cash conversion cycle terhadap cash holding telah dibuktikan oleh Senjaya \& Yadnyana (2016) yang mengatakan bahwa cash conversion cycle tidak berpengaruh signifikan dan arahnya positif. Namun hasil penelitian Humendru \& Pangaribuan (2018) conversion cycle berpengaruh signifikan dengan arah positif. Sedangkan Wulandari \& Setiawan (2019) dan William \& Fauzi (2013) mengatakan bahwa cash conversion cycle berpengaruh signifikan dengan arah negatif terhadap cash holding. Penelitian yang dilakukan oleh Ariana, Hadjaat, \& Yudaruddin (2018) mengatakan bahwa operating cash flow tidak berpengaruh signifikan arahnya positif terhadap cash holding. Sedangkan hasil penelitian Hadiwijaya \& Trisnawati (2019) operating cash flow berpengaruh signifikan dan arahnya positif terhadap cash holding. Pada penelitian yang dilakukan oleh Humendru \& Pangaribuan (2018) growth opportunity tidak berpengaruh signifikan dengan arah positif, sedangkan penelitian William \& Fauzi (2013) berpengaruh signifikan dengan arah positif.

Berdasarkan fenomena dan reseach gap tersebut masih terdapat ketidakkonsistenan dari berbagai penelitian serta penelitian ini merupakan pengembangan penelitian yang dilakukan oleh Maarif, Anwar, \& Darmansyah (2019) yang berjudul Pengaruh Interest Income Growth, 
Net Working Capital, dan Capital Expenditure terhadap Cash Holding dengan Aktivitas Dewan Komisaris sebagai Variabel Moderasi. Oleh karena itu, peneliti tertarik untuk menguji ulang mengenai faktor-faktor yang mempengaruhi cash holding. Adapun perbedaan penelitian ini dengan penelitian sebelumnya yaitu dengan menambahkan variabel cash conversion cycle, operating cash flow, dan growth opportunity sebagai variabel independen dikarenakan ketidakkonsistenan pada berbagai penelitian. Selanjutnya peneliti menggunakan sampel perusahaan yang akan diteliti, karena melihat dari fenomena yang telah dijelaskan dalam latar belakang tersebut.

Penelitian ini menggunakan variabel good corporate governace sebagai variabel moderasi. Menurut Organization For Economic Co Operation and Development (OECD) pengertian dari corporate governance adalah suatu sekumpulan hubungan antara pihak manajemen perusahaan, dewan perusahaan, dan para pemegang saham, serta pihak lain yang memiliki kepentingan dengan perusahaan terkait. Corporate governance juga mensyaratkan adanya struktur perangkat yang gunanya adalah untuk mencapai tujuan dan pengawasan atas kinerja.

Dengan menggunakan corporate governance sebagai variabel moderasi diharapkan dapat mengetahui apakah corporate governance dapat berpengaruh kuat atau lemah terhadap cash holding. Di samping itu dengan menggunakan corporate governance diharapkan dapat memonitoring dan mengevaluasi kinerja perusahaan untuk dapat meningkatkan likuiditas agar tersedianya kas dan setara kas. Hal ini dikarenakan pada dasarnya corporate governance merupakan aktivitas pengendalian internal perusahaan yang terstruktur. Apabila corporate governance perusahaan sudah baik maka dapat mencegah atau mengurangi perusahaan terhadap terjadinya kesulitan keuangan. Berdasarkan latar belakang di atas maka penelitian ini dilakukan untuk menganalisis pengaruh net working capital, capital expenditure, cash conversion cycle, cash flow, dan growth opportunity terhadap cash holding dengan corporate governance sebagai variabel moderating (studi kasus perusahaan industri barang konsumsi yang terdaftar pada Bursa Efek Indonesia tahun 2014-2018).

\section{B. TELAAH PUSTAKA}

\section{Pecking Order Theory}

Pecking Order Theory yang dikemukakan oleh Husnan \& Pudjiastuti (2015) menjelaskan bahwa mengapa perusahaan akan menentukan hierarki sumber dana yang paling disukai. Pecking order theory menjelaskan tentang pemilihan alternatif sumber pembiayaan 
perusahaan, dimana dijelaskan teori ini bahwa penggunaan sumber dana internal (laba ditahan dan cash holding) menjadi pilihan utama perusahaan. Kas disebut berperan sebagai penyangga antara laba ditahan dengan kebutuhan investasi, sehingga saat laba ditahan serta kas tidak lagi mencukupi maka barulah digunakan pembiayaan eksternal (Liestyasih \& Wiagustini, 2017).

\section{Agency Theory}

Teori ini ditemukan oleh Jansen dan Mecking pada tahun 1976 yang menyatakan bahwa kedua belah pihak yakni pemilik dan pengelola akan berusaha memaksimumkan utilitas mereka. Dengan demikian, terdapat kemungkinan pihak manajemen tidak selalu bertindak sesuai dengan kepentingan pemegang saham. Konflik kepentingan pemegang saham dan manajemen salah satunya dapat timbul karenanya adanya kelebihan aliran kas (excess cash flow). Kelebihan tersebut cenderung diinvestasikan ke hal-hal yang tidak ada kaitannya dengan kegiatan utama perusahaan. Teori agensi, biaya agensi dapat dikurangi dengan adanya kepemilikan saham oleh manajerial. Oleh karena itu, masalah keagenan merupakan faktor penentu dari cash holding perusahaan karena adanya biaya agensi dapat mempengaruhi manajer.

\section{Cash Holding}

Menurut Gill \& Shah (2012) cash holding merupakan kas yang ada di tangan atau tersedia untuk diinvestasikan dalam bentuk aset fisik dan untuk dibagikan kepada investor. Dalam penelitian Siddiqua, Rehman, \& Hussain (2019) mengatakan bahwa cash holding tersebut dapat diukur dengan membagi kas dan setara kas perusahaan dengan total asetnya.

\section{Good Corporate Governanace}

Penelitian ini menggunakan corporate governance sebagai variabel moderasi dan menggunakan aktivitas dewan komisaris sebagai pengukuran. Maarif, Anwar, \& Darmansyah (2019) mengatakan bahwa aktivitas dewan komisaris merupakan suatu mekanisme corporate governance berupa media dalam mengawasi dan memberikan petunjuk serta arahan pada manajemen. Rapat dewan komisaris secara periodik dilakukan dengan tujuan dapat mencegah dan mengurangi kemungkinan terjadinya kondisi kesulitan keuangan karena aktivitas pengendalian internal perusahaan dilakukan secara terus menerus dan terstruktur. Dengan demikian setiap permasalahan dapat cepat terdeteksi dan diselesaikan dengan baik oleh manajemen. 


\section{Net Working Capital}

Menurut Boriçi \& Kruja (2016) modal kerja bersih didefinisikan sebagai perbedaan antara aktiva lancar dikurangi dengan total kas dan setara kas. Modal kerja mengukur kemampuan untuk membayar kewajiban lancar dengan aset lancar. Secara umum, semakin besar modal kerja, semakin besar kemampuan untuk membayar utang (Muharromah, Ahmar, \& Anwar, 2019).

\section{Capital Expenditure}

Capital expenditure diartikan sebagai kegiatan investasi yang dilakukan oleh perusahaan dengan menggunakan aset tetap atau fixed asset sebagai media investasinya Trinh \& Thuy Mai (2016). Sedangkan menurut penelitian yang dilakukan oleh Monica, Susanti, \& Dewi (2019) capital expenditure atau belanja modal terjadi ketika perusahaan melakukan pengeluaran untuk diinvestasikan aset tetap.

\section{Cash Conversion Cycle}

Horne \& Wachowicz (2013) menyebutkan bahwa siklus konversi kas adalah lamanya waktu yang diperlukan dari pengeluaran kas yang sesungguhnya untuk pembelian hingga penagihan piutang yang merupakan hasil dari penjualan barang atau jasa.

\section{Cash Flow}

Cash flow adalah laporan keuangan yang terdiri dari transaksi investasi, kegiatan operasi dan kegiatan transaksi pembiayaan/pendanaan, dimana setiap transaksi dibedakan sesuai dengan golongannya dan khusus menghitung tentang kas masuk dan keluar dalam satu periode (Horne \& Wachowicz, 2013).

\section{Growth Opprortunity}

Menurut William dan Fauzi (2013), growth opportunity (kesempatan pertumbuhan) merupakan suatu perpaduan antara kemungkinan peluang investasi di masa depan dengan aktiva nyata yang dimiliki oleh suatu perusahaan. Sedangkan, menurut Burhanuddin dan Yusuf (2019), growth opportunity adalah seberapa besar perusahaan mampu menempatkan diri pada sistem ekonomi secara keseluruhan atau sistem ekonomi untuk industri yang sama.

\section{Hubungan Logis Antar Variabel dan Perumusan Hipotesis}

\section{Pengaruh Net Working Capital terhadap Cash Holding}

Semakin tinggi nilai net working capital maka kas yang dipegang oleh perusahaan semakin tinggi, karena kas merupakan bagian dari net working capital. Dengan demikian, jika kas yang dipegang oleh perusahaan meningkat maka perusahaan cenderung menahan kas lebih banyak. Sebaliknya, semakin rendah hasil dari net working capital menunjukkan bahwa 
semakin sedikit pula kas yang dimiliki oleh perusahaan. Maarif, Anwar, \& Darmansyah (2019) berpendapat bahwa net working capital tidak berpengaruh signifikan dan tandanya positif, sedangkan hasil penelitian Wulandari \& Setiawan (2019) dan William \& Fauzi (2013) berpengaruh signifikan dan positif. Berdasarkan rumusan yang telah diuraikan tersebut maka hipotesis yang dapat diajukan adalah sebagai berikut:

$\mathrm{H}_{1}$ : Net working capital berpengaruh positif terhadap cash holding

\section{Pengaruh Capital Expenditur terhadap Cash Holding}

Semakin tinggi capital expenditure mengindikasi bahwa semakin banyak kas yang harus dikeluarkan untuk kebutuhan investasi sehingga perusahaan akan cenderung menahan kas dalam pembiayaan investasi. Sebaliknya semakin rendah capital expenditure, maka kebutuhan kas akan investasi semakin sedikit dan perusahaan tidak akan menahan kas tersebut dan cenderung kas yang dimiliki oleh perusahaan akan sedikit. Penelitian yang dilakukan oleh Maarif, Anwar, \& Darmansyah (2019) dan Ariana, Hadjaat, \& Yudaruddin, (2018) dengan hasil capital expenditure positif, tidak berpengaruh signifikan terhadap cash holding. Sedangkan menurut penelitian Yanti, Susanto, Wirianta, \& Viriany, Maret (2019) hasilnya berpengaruh signifikan dan tandanya negatif. Namun, penelitian Hadiwijaya \& Trisnawati (2019) hasilnya berpengaruh signifikan dan positif. Berdasarkan rumusan yang telah diuraikan tersebut maka hipotesis yang dapat diajukan adalah sebagai berikut:

\section{$\mathrm{H}_{2}$ : Capital expenditure berpengaruh positif terhadap cash holding}

\section{Pengaruh Cash Conversion Cycle terhadap Cash Holding}

Siklus konversi kas adalah lamanya waktu yang diperlukan dari pengeluaran kas yang sesungguhnya untuk pembelian hingga penagihan piutang yang merupakan hasil dari penjualan barang atau jasa (Horne \& Wachowicz, 2013). Perputaran kas yang tercermin dari siklus konversi kas tentunya akan mempengaruhi saldo kas pada waktu tertentu. Semakin pendek periode proses perputaran kas maka semakin cepat cash turnover yang akan dihasilkan, dan sebaliknya. Semakin cepat cash turnover maka perusahaan akan mengurangi saldo kas pada perusahaan, karena cash turnover tersebut dapat berperan sebagai medium pembiayaan aktivitas operasional. Sedangkan perusahaan yang memiliki siklus konversi kas yang lama umumnya memiliki saldo kas dalam jumlah yang besar (William \& Fauzi, 2013).

Berdasarkan uraian tersebut, dapat disimpulkan bahwa apabila siklus konversi kas yang berlangsung pada perusahaan memakan waktu yang lama menunjukkan semakin lama pula kas yang terkumpul atas penjualan produk yang telah dilakukan oleh perusahaan. Hal ini menyebabkan ebutuhan akan pendanaan internal perusahaan untuk membiayai operasional 
perusahaan semakin besar sehingga perusahaan akan lebih menahan kas (cash holding). Sebaliknya, jika siklus konversi kas yang berlangsung secara singkat perusahaan tidak memerlukan kas yang besar untuk membiayai operasional perusahaan karena perusahaan dapat memperoleh kas dengan cepat atas penjualan produk. Oleh karena itu, kas perusahaan dapat digunakan sebagai pembiayaan investasi dan memperoleh pendapatan yang lebih tinggi.

Pernyataan tersebut mengenai cash conversion cycle terhadap cash holding telah dibuktikan oleh Senjaya \& Yadnyana (2016) mengatakan bahwa cash conversion cycle tidak berpengaruh signifikan dan arahnya positif. Namun hasil penelitian Humendru \& Pangaribuan (2018) conversion cycle berpengaruh signifikan dengan arah positif. Sedangkan Wulandari \& Setiawan (2019) dan William \& Fauzi (2013) mengatakan bahwa cash conversion cycle berpengaruh signifikan dengan arah negatif terhadap cash holding. Berdasarkan rumusan yang telah diuraikan maka hipotesis yang dapat diajukan adalah sebagai berikut:

$\mathrm{H}_{3}$ : Cash conversion cycle berpengaruh terhadap cash holding

\section{Pengaruh Cash Flow terhadap Cash Holding}

Saat arus kas operasional tinggi perusahaan menggunakannya untuk membiayai proyek baru yang menguntungkan, untuk membayar liabilitas, untuk membayar dividen, dan sisanya untuk ditahan sebagai kas. Hasil penelitian ini sejalan dengan teori tersebut yaitu cash flow berpengaruh positif terhadap cash holding. Karena saat cash flow yang masuk pada perusahaan besar maka perusahaan menggunakannya untuk membayar dividen, ditahan sebagai kas, membayar liabilitas. Oleh karena itu, untuk arus kas masuk yang besar tergantung pada operasional suatu perusahaan. Hal ini dapat menjadi perhatian perusahaan untuk mengelola arus kas dengan baik. Saat arus kas masuk yang besar maka cash flow yang dimiliki perusahaan tersebut positif. Cash flow yang positif menyebabkan meningkatnya tingkat cash holding yang tersedia di perusahaan Ariana, Hadjaat, \& Yudaruddin (2018).

Apabila perusahaan memiliki cash flow jumlah yang besar maka cenderung untuk memegang kas lebih besar karena kas tersebut akan digunakan sebagai pembayaran biaya operasional, investasi serta pendanaan. Oleh karena itu, perusahaan akan menahan kas (cash holding) lebih banyak. Sebaliknya, apabila cash flow perusahaan cenderung rendah maka kas yang ada pada perusahaan lebih sedikit. Penelitian yang dilakukan oleh Ariana, Hadjaat, \& Yudaruddin (2018) mengatakan bahwa operating cash flow tidak berpengaruh dan tidak signifikan arahnya positif terhadap cash holding. Sedangkan hasil penelitian Hadiwijaya \& 
Trisnawati (2019) operating cash flow berpengaruh signifikan dan arahnya positif terhadap cash holding. Berdasarkan rumusan yang telah diuraikan tersebut maka hipotesis yang dapat diajukan adalah sebagai berikut:

$\mathrm{H}_{4}$ : Cash Flow berpengaruh positif terhadap Cash Holding

\section{Pengaruh Growth Opportunity terhadap Cash Holding}

Growth opportunity (kesempatan pertumbuhan) merupakan suatu perpaduan antara kemungkinan peluang investasi di masa depan dengan aktiva nyata yang dimiliki oleh suatu perusahaan William \& Fauzi (2013). Berdasarkan trade-off theory dalam penelitian Humendru \& Pangaribuan (2018) menilai cash holding yang optimal yaitu dengan mempertimbangkan biaya yang ditimbulkan dari memegang kas tersebut dengan manfaat yang akan didapatkan perusahaan. Artinya, apabila manfaat yang didapatkan perusahaan lebih besar daripada biaya yang ditimbulkan dari memegang kas maka perusahaan cenderung menahan kas jumlah banyak. Perusahaan dengan tingkat pertumbuhan yang tinggi akan melakukan penahanan kas jumlah besar untuk membiayai pertumbuhannya, karena manfaat yang didapatkan perusahaan lebih besar daripada biaya yang ditimbulkan dari memegang kas.

Berdasarkan uraian tersebut, dapat disimpulkan semakin tingginya growth opportunity atau kesempatan investasi akan mendorong perusahaan untuk lebih banyak menahan kas dengan tujuan membiayai investasi supaya perusahaan lebih mudah untuk berkembang di masa yang akan datang. Pernyataan tersebut mengenai growth opportunity pada penelitian yang dilakukan Humendru \& Pangaribuan (2018) menunjukkan hasil tidak berpengaruh dan tidak signifikan dengan arah positif. Sedangkan penelitian William \& Fauzi (2013) berpengaruh signifikan dengan arah positif. Berdasarkan rumusan yang telah diuraikan tersebut maka hipotesis yang dapat diajukan adalah sebagai berikut:

$\mathrm{H}_{5}$ : Growth opportunity berpengaruh positif terhadap cash holding

\section{Pengaruh Net Working Capital terhadap Cash Holding dengan Corporate Governance sebagai Variabel Moderating}

Tata kelola perusahaan yang baik adalah suatu sistem yang mengatur hubungan dan peran berbagai pemangku kepentingan misalnya: dewan komisaris, peran direksi, dan pemegang saham (Yanti, Susanto, Wirianta, \& Viriany, Maret, 2019). Dengan adanya hal tersebut karena terdapatnya good corporate governance dalam suatu perusahaan mendorong untuk dapat terbentuk pola kerja manajemen yang bersih, transparan, dan profesional. Tata kelola perusahaan bertugas untuk mengatur hubungan perusahaan antara manajemen dengan stakeholder sebagai pemilik perusahaan. Diketahui bahwa pemilik perusahaan tidak secara 
langsung dapat mengelola perusahaan. Oleh karena itu, diperlukan pengawasan supaya perusahaan dapat mengelola dan mengatur sebaik mungkin untuk dapat mencapai tujuannya yaitu memaksimalkan keuntungan perusahaan.

Hasil penelitian yang dilakukan oleh Maarif, Anwar, \& Darmansyah (2019) mengatakan bahwa dewan komisaris yang merupakan bagian dari good corporate governance terhadap cash holding yang dimoderasi oleh aktivitas dewan komisaris tidak signifikan. Kontrol yang dilakukan oleh dewan komisaris sudah baik dilakukan, sehingga semakin sering dilakukan rapat dewan komisaris akan meningkatkan pengeluaran kas, dengan demikian tingkat likuiditas (NWC) tidak terpengaruh oleh peran aktivitas dewan komisaris dalam menahan kas (cash holding). Namun, Islam (2012) mengatakan bahwa ketika dibutuhkan, net working capital dapat dilikuidasi dengan cepat untuk menutupi kekurangan kas yang dibutuhkan perusahaan. Dengan hal tersebut dapat disimpulkan bahwa apabila tata kelola perusahaan baik, maka hasil dari net working capital akan surplus. Dengan demikian, perusahaan tidak perlu mengalami kesulitan keuangan dan tidak perlu untuk membuat cadangan kas atau menahan kas. Berdasarkan rumusan yang telah diuraikan tersebut maka hipotesis yang dapat diajukan adalah sebagai berikut :

$\mathrm{H}_{6}$ : Net working capital berpengaruh positif terhadap cash holding dengan corporate governance sebagai variabel moderating.

\section{Pengaruh Capital Expenditure terhadap Cash Holding dengan Corporate Governance sebagai Variabel Moderating}

Menurut (Pedoman Umum Good Corporate Governance Indonesia, 2006) salah satu tujuan good corporate governance yaitu meningkatkan daya saing perusahaan secara nasional maupun internasional, sehingga meningkatkan kepercayaan pasar yang dapat mendorong arus investasi dan pertumbuhan ekonomi nasional yang berkesinambungan. Untuk dapat mendorong arus investasi terhadap perusahaan harus memiliki rencana untuk melakukan investasi di masa depan dengan memperbaiki atau menciptakan aset baru guna menunjang kinerja perusahaan. Capital expenditure yang dibutuhkan perusahaan cenderung menahan kas atau membuat cadangan kas untuk menjaga kelangsungan dalam pengerjaannya.

Terdapat penelitian terdahulu yang menggunakan corporate governace sebagai variabel moderating seperti yang dilakukan oleh Maarif, Anwar, \& Darmansyah (2019) mengatakan bahwa dewan komisaris sebagai proksi corporate governace penelitian ini bahwa terdapat pengaruh signifikan antara capital expenditure terhadap cash holding dan aktivitas dewan komisaris dapat sebagai variabel moderating. Penelitian yang dilakukan Maarif, Anwar, \& 
Darmansyah (2019) mengatakan semakin meningkatnya capital expenditure diperkuat oleh aktivitas dewan komisari. Hal ini menunjukkan bahwa peran kontrol dewan komisaris berhubungan dengan belanja modal, karena belanja modal perusahaan dilakukan oleh kebijakan manajemen dalam pasar uang dan pasar modal. Dengan demikian aktivitas dewan komisaris mendukung ketersediaan kas karena kegiatan belanja modal (capital expenditure). Berdasarkan rumusan yang telah diuraikan tersebut maka hipotesis yang dapat diajukan adalah sebagai berikut :

$\mathrm{H}_{7}$ : Capital expenditure berpengaruh terhadap cash holding dengan corporate governance sebagai variabel moderating.

\section{Pengaruh Cash Conversion Cycle terhadap Cash Holding dengan Corporate Governance sebagai Variabel Moderating}

Pengelolaan arus kas yang dilakukan oleh perusahaan biasanya pihak manajemen lebih banyak memiliki informasi mengenai keuangan perusahaan dibanding pemegang saham sehingga menyebabkan terjadinya asimetri informasi antara manajer dengan pemegang saham atau investor (Sadono, 2016). Lemahnya tata kelola perusahaan dapat mengakibatkan buruknya manajemen kas, manajemen piutang, persediaan, utang usaha, serta siklus konversi kas perusahaan. Dengan adanya tata kelola perusahaan yang baik atau good corporate governance yang merupakan salah satu komponen yang berperan penting dan berpengaruh terhadap pengelolaan perusahaan agar dapat mencapai nilai perusahaan yang optimal.

Sejalan dengan penelitian Sadono (2016) yang mengatakan perusahaan perlu menerapkan corporate governance untuk memberikan informasi yang simetris antara kedua belah pihak. Penerapan corporate governance yang baik dapat mengurangi adanya asimetri informasi karena perusahaan akan memberikan lebih banyak informasi yang dapat mengurangi asimetri informasi tersebut. Sehingga dengan diterapkannya tata kelola perusahaan yang baik diharapkan dapat mempercepat siklus konversi kas sehingga penerimaan kas dapat berlangsung secara singkat. Oleh karena itu, perusahaan tidak memerlukan kas yang besar untuk membiayai operasional perusahaan karena perusahaan dapat memperoleh kas dengan cepat atas penjualan produk. Kas perusahaan dapat digunakan sebagai pembiayaan investasi dan memperoleh pendapatan yang lebih tinggi.

Menurut Sadono (2016) corporate governance tidak berpengaruh signifikan dengan arah positif terhadap siklus konversi kas (cash conversion cycle). Penelitian ini tidak sejalan dengan Gill \& Biger (2013) yang mengatakan bahwa corporate governance mempengaruhi siklus konversi kas. Sejalan dengan Ajanthan \& Kumara (2017) yang meneliti mengenai 
corporate governance dengan semakin banyaknya dewan komisaris melakukan rapat maka dapat menguntungkan perusahaan yang terdaftar di Bursa Sri Lanka untuk mengatur tingkat perusahaan dengan cara yang efisien. Temuan ini juga menunjukkan hubungan negatif yang signifikan terhadap cash conversion cycle. Berdasarkan rumusan yang telah diuraikan tersebut maka hipotesis yang dapat diajukan adalah sebagai berikut :

$\mathrm{H}_{8}$ : Cash conversion cycle berpengaruh terhadap cash holding dengan corporate governance sebagai variabel moderating.

\section{Pengaruh Cash Flow terhadap Cash Holding dengan Corporate Governance sebagai Variabel Moderating}

Tata kelola perusahaan yang baik merupakan upaya untuk mengatur, mengendalikan, dan mengatasi perilaku manajemen. Oleh karena itu, dengan adanya tata kelola perusahaan diharapkan dapat sebagai kontrol perusahaan untuk menciptakan kinerja yang efektif dan efisien sehingga dapat memberikan keuntungan kepada semua pihak. Penelitian (Nagar \& Raithatha, 2016) mengatakan bahwa perusahaan di negara berkembang, regulasi dan tata kelola perusahaan relatif lebih lemah dibandingkan dengan di pasar negara maju seperti Inggris. Selanjutnya, sebagian besar perusahaan yang berafiliasi dengan kelompok-kelompok bisnis dan sedang dijalankan oleh anggota keluarga pendiri.

Diharapkan tata kelola perusahaan dapat dikendalikan dengan baik sehingga dapat meningkatkan kinerja perusahaan yang akan berpengaruh pada arus kas yang masuk pada perusahaan lebih besar dari pada arus kas keluar sehingga arus kas bersih perusahaan positif. Selanjutnya, tata kelola dapat meningkatkan jumlah kas perusahaan guna melakukan investasi dan pendanaan. Dengan melakukan investasi dapat memberikan kesempatan perusahaan untuk dapat memperoleh keuntungan dan mengoptimalkan kas, di samping itu dengan melakukan pendanaan dan membayar hutang atau membagikan dividen kepada perusahaan dapat memberikan kesejahteraan kepada investor dan stakeholders.

Hasil penelitian Nagar \& Raithatha (2016) menunjukkan pemerintah dan komite audit secara bersama-sama mengendalikan secara efektif arus kas supaya tidak terjadi manipulasi. Nagar \& Raithatha (2016) juga menemukan bahwa manipulasi seperti telah terjadi penurunan dalam beberapa tahun terakhir, mungkin karena langkah-langkah baru ini yang diambil oleh pemerintah India untuk meningkatkan lingkungan tata kelola perusahaan di India. Sejalan dengan (Pedoman Umum Good Corporate Governance Indonesia, 2006) mengatakan bahwa tujuan dari good corporate governance yaitu dengan mengoptimalkan nilai perusahaan bagi 
pemegang saham dengan tetap memperhatikan pemangku kepentingan lainnya. Berdasarkan rumusan yang diuraikan tersebut maka hipotesis yang dapat diajukan adalah sebagai berikut:

$\mathrm{H}_{9}$ : Cash flow berpengaruh terhadap cash holding dengan corporate governance sebagai variabel moderating.

\section{Pengaruh Growth Opportunity terhadap Cash Holding dengan Corporate Governance sebagai Variabel Moderating}

Menurut Dogru \& Turk (2018) perusahaan dengan growth opportunity yang tinggi mungkin menyimpan uang tunai lebih banyak dari pada cash flow. Mungkin pula perusahaan bergantung pada uang tunai untuk investasi karena mereka memiliki lebih banyak peluang investasi untuk mengeksploitasi dan mungkin perlu semua sumber daya yang tersedia untuk keuangan yang akan diinvestasi pada perusahaan. Menurut Abor \& Bokpi (2010) mengatakan bahwa di pasar negara berkembang, semakin tingginya pertumbuhan perusahaan maka dividen yang akan dibayarkan semakin rendah. Sejalan argumen Dogru \& Turk (2018) pemegang saham pertumbuhan perusahaan yang tinggi maka mempersepsikan bahwa laba ditahan akan lebih melayani laba dengan tujuan maksimalisasi pertumbuhan perusahaan daripada mendistribusikan kelebihan uang tunai sebagai dividen.

Corporate governance dapat sebagai pengendali perusahaan untuk mengatur, mengendalikan dan mengatasi perilaku manajemen supaya dapat mengontrol perusahaan dengan menciptakan kinerja yang efektif. Sejalan dengan penelitian Saragih (2018) investor akan lebih merasa aman ketika perusahaan menerapkan corporate goveranance yang baik. Maka hal ini akan memberikan nilai tambah bagi perusahaan terhadap investor, karena memberikan pandangan terhadap investor bahwasanya perusahaan tersebut di kelola dengan baik. Good corporate governance nantinya akan memperkuat pengaruh hubungan growth opportunity terhadap cash holding. Semakin perusahaan memiliki growth opportunity yang tinggi atau kesempatan investasi maka akan mendorong perusahaan untuk lebih banyak menahan kas. Hal ini dilakukan dengan tujuan membiayai investasi supaya perusahaan lebih mudah untuk berkembang di masa yang akan datang. Berdasarkan rumusan yang telah diuraikan tersebut maka hipotesis yang dapat diajukan adalah sebagai berikut :

$H_{10}$ : Growth opportunity berpengaruh terhadap cash holding dengan corporate governance sebagai variabel moderating. 


\section{Kerangka Pemikiran}

Gambar 2. Kerangka Pemikiran

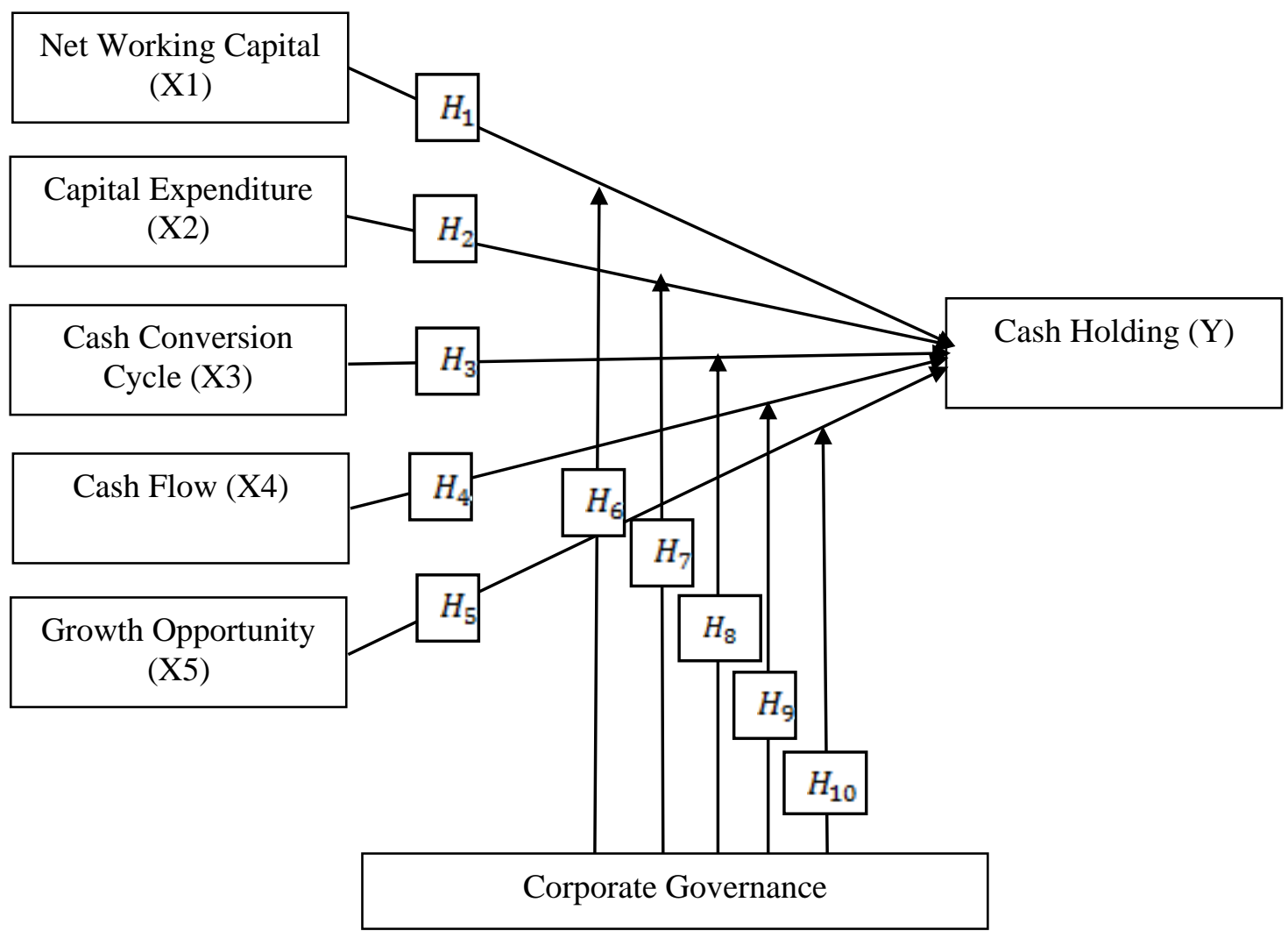

Berdasarkan tinjauan pustaka dan mengacu dari beberapa hasil penelitian yang telah dijelaskan sebelumnya yang berkaitan mengenai pengaruh net working capital, capital expenditure, cash conversion cycle, cash flow, dan growth opportunity terhadap cash holding dengan corporate governance sebagai variabel moderating. Maka kerangka pemikiran yang mendasari penelitian ini dapat dilihat pada gambar 2 .

\section{METODOLOGI PENELITIAN}

\section{Populasi dan Sampel Penelitian}

Populasi yang digunakan penelitian ini adalah seluruh perusahaan sektor industri barang konsumsi yang tercatat di Bursa Efek Indonesia selama tahun 2014-2018. Jumlah populasi yang digunakan pada penelitian setelah melalui metode purposive sampling yaitu sebanyak 30 sampel perusahaan. Jenis data yang digunakan berupa data sekunder, yaitu data diperoleh atau dikumpulkan oleh peneliti dari berbagai sumber yang telah ada. Metode analisis data yang digunakan untuk pengujian hipotesis menggunakan program WarpPLS 6.0. 


\section{Definisi Operasional Variabel}

Tabel 1. Definisi Operasional Variabel

\begin{tabular}{|c|c|c|}
\hline Variabel & Definisi & Indikator \\
\hline $\begin{array}{l}\text { Cash } \\
\text { Holding }\end{array}$ & $\begin{array}{l}\text { Kas merupakan salah satu bentuk aset likuid yang } \\
\text { berbentuk sejumlah uang kartal yang dimiliki oleh } \\
\text { perusahaan dimana dapat disimpan sebagai kas kecil } \\
\text { (petty cash), atau kas register, atau bentuk rekening } \\
\text { rekening baik itu di bank (William \& Fauzi, 2013) }\end{array}$ & $\begin{array}{l}\text { Cash Holding } \\
\text { Kas dan setara kas } \\
\text { Total aset }\end{array}$ \\
\hline $\begin{array}{l}\text { Aktivitas } \\
\text { Dewan } \\
\text { Komisaris }\end{array}$ & $\begin{array}{l}\text { Aktivitas Dewan Komisaris merupakan suatu } \\
\text { mekanisme corporate governance berupa media } \\
\text { sebagai mengawasi dan memberikan petunjuk serta } \\
\text { arahan pada manajemen (Maarif, Anwar, \& } \\
\text { Darmansyah, 2019) }\end{array}$ & $\begin{array}{l}\text { ADK = Jumlah rapat dewan } \\
\text { komisaris dalam satu tahun }\end{array}$ \\
\hline $\begin{array}{l}\text { Net } \\
\text { Working } \\
\text { Capital }\end{array}$ & $\begin{array}{l}\text { Menurut (Boriçi \& Kruja, 2016) modal kerja bersih } \\
\text { didefinisikan sebagai perbedaan antara aktiva lancar } \\
\text { dikurangi dengan total kas dan setara kas. }\end{array}$ & $\begin{array}{l}\text { NWC }= \\
\frac{\text { Net Current Asset-Kas\& Setara kas }}{\text { Total Asset - Kas \& Setara Kas }} \\
\text { NWC }= \\
\frac{\text { Akttva Lancar -Hutang Lancar }}{\text { Total Asset }} \times 100 \%\end{array}$ \\
\hline $\begin{array}{l}\text { Capital } \\
\text { Expenditure }\end{array}$ & $\begin{array}{l}\text { Capital expenditure dapat diartikan sebagai kegiatan } \\
\text { investasi yang dilakukan oleh perusahaan dengan } \\
\text { menggunakan aset tetap atau fixed asset sebagai } \\
\text { media investasinya (Trinh \& Thuy Mai, 2016) }\end{array}$ & $\begin{array}{l}\text { CAPEX }= \\
\frac{\text { Asset tetap }_{\mathrm{t}^{-}} \text {Asset tetap }(\mathrm{t}-\mathrm{x})}{\text { Total Asset }} \\
\end{array}$ \\
\hline $\begin{array}{l}\text { Cash } \\
\text { Conversion } \\
\text { Cycle }\end{array}$ & $\begin{array}{l}\text { Siklus konversi kas adalah lamanya waktu yang } \\
\text { diperlukan dari pengeluaran kas yang } \\
\text { sesungguhnya untuk pembelian hingga penagihan } \\
\text { piutang yang merupakan hasil dari penjualan } \\
\text { barang atau jasa (Horne \& Wachowicz, 2013) }\end{array}$ & $\begin{array}{l}\text { CCC = Days Inventory }+ \\
\text { Days Receivable - Days } \\
\text { Payable }\end{array}$ \\
\hline Cash Flow & $\begin{array}{l}\text { Menurut (Horne \& Wachowicz, 2013) cash flow } \\
\text { adalah laporan keuangan yang terdiri dari transaksi } \\
\text { investasi, kegiatan operasi dan kegiatan transaksi } \\
\text { pembiayaan/pendanaan, dimana setiap transaksi di } \\
\text { bedakan sesuai dengan golongannya dan khusus } \\
\text { menghitung tentang kas masuk dan keluar dalam } \\
\text { satu periode }\end{array}$ & Cash Flow $=\frac{\text { Arus Kas Operastonal }}{\text { Total asset }}$ \\
\hline \multirow[t]{2}{*}{$\begin{array}{l}\text { Growth } \\
\text { Opportunity }\end{array}$} & \multirow{2}{*}{$\begin{array}{l}\text { Growth opportunity (kesempatan pertumbuhan) } \\
\text { merupakan suatu perpaduan antara kemungkinan } \\
\text { peluang investasi di masa depan dengan aktiva } \\
\text { nyata yang dimiliki oleh suatu perusahaan (William } \\
\text { \& Fauzi, 2013) }\end{array}$} & $\begin{aligned} \mathrm{GO}= & \frac{\text { Penfualan }_{\mathrm{t}}-\text { Penfualan }_{(\mathrm{t}-1)}}{\text { Penfualan }_{(\mathrm{t}-1)}} \\
& \text { Total Asset }_{\mathrm{t}}-\text { Total Asset }_{(\mathrm{t}-\mathrm{1})}\end{aligned}$ \\
\hline & & $\mathrm{GO}=\quad$ TotalAsset $_{(\mathrm{t}-\mathrm{1})}$ \\
\hline
\end{tabular}

\section{Metode Analisis}

Metode analisis yang digunakan dalam penelitian ini yaitu menggunakan analisis kuantitatif. Metode kuantitatif merupakan pendekatan ilmiah terhadap pengambilan keputusan manajerial dan ekonomi. Metode dalam penelitian ini yaitu menggunakan analisis regresi linier partial (Partial Least Square/PLS) guna menguji penelitian dari beberapa 
hipotesis yang telah diajukan. Oleh karena itu hipotesis tersebut akan dianalisis dengan software WarpPLS 6.0 untuk menguji hubungan antar variabel dalam penelitian.

\section{Metode Partial Least Square (PLS)}

Dalam penelitian ini menggunakan metode Partial Least Square (PLS). Partial least square merupakan metode analisis yang powerfull oleh karena tidak didasarkan banyak asumsi. Metode PLS mempunyai keunggulan diantaranya adalah data tidak harus berdisitribusi normal multivariate (indikator dengan skala kategori, ordinal, interval sampai ratio dapat digunakan pada model yang sama). Selain dapat digunakan untuk mengonfirmasi teori, PLS juga dapat digunakan untuk menjelaskan ada atau tidaknya hubungan antar variabel laten atau tujuan prediksi (Ghozali, 2011).

Partial least square merupakan teknik statistika multivariat yang membandingkan antara variabel independen berganda dan variabel dependen berganda. Selain itu, PLS juga merupakan salah satu metode statistik SEM yang berbasis varian untuk dapat menyelesaikan regresi berganda saat terjadi permasalahan spesifik pada data, misalnya untuk ukuran sampel penelitian yang kecil dan adanya data yang hilang serta multikolinearitas. SEM merupakan suatu metode statistik multivariate yang membantu peneliti untuk menguji teori dan riset empiris yang didukung oleh data.

Dalam penelitian ini memilih menggunakan metode PLS dikarenakan bahwa penelitian tersebut terdapat tiga variabel laten yang dibentuk dengan indikator reflektif dan membentuk efek moderating. Model refleksif mengasumsikan bahwa konstruk atau variabel laten mempengaruhi indikator (arah hubungan kausalitas dari konstruk ke indikator atau manifest). Model indikator refleksif harus memiliki internal konsistensi oleh karena semua ukuran indikator diasumsikan semuanya valid indikator yang mengukur suatu konstruk, sehingga dua ukuran indikator yang sama reliabilitasnya (cronbach alpha) dapat saling dipertukarkan. Metode Partial Least Square didasarkan pada pergeseran analisis dari pengukuran estimasi parameter model menjadi pengukuran prediksi yang relevan. Dengan demikian, fokus analisis bergeser dari hanya estimasi dan penafsiran signifikan parameter menjadi validitas dan akurasi prediksi.

\section{Teknik Analisis Data}

\section{Statistik Deskriptif}

Uji statistik deskriptif dilakukan untuk memberikan gambaran data sampel yang digunakan dalam penelitian. Statistik deskriptif yang akan ditampilkan pada penelitian ini terdiri dari nilai minimum, maksimum, mean serta standar deviasi. Dalam memudahkan 
perhitungan dan memberikan gambaran statistik deskriptif dalam penelitian ini menggunakan program SPSS 22.

\section{Evaluasi Model Pengukuran}

Penelitian ini menggunakan evaluasi model pengukuran dengan melakukan evaluasi model menggunakan PLS meliputi 2 tahap, yaitu evaluasi outer model atau model pengukuran dan evaluasi terhadap inner model atau model struktural.

\section{Evaluasi Model Pengukuran (Outer Model)}

Menurut (Yamin \& Heri, 2011) Outer Model menentukan spesifikasi hubungan antara konstruk laten dengan indikatornya. Berikut merupakan persamaan outer model:

$$
\begin{aligned}
& \mathrm{X}=\pi_{x} \varepsilon+\varepsilon_{x} \\
& \mathrm{X}=\pi_{y} \eta+\varepsilon_{y}
\end{aligned}
$$

Keterangan

$\mathrm{X}=$ Matrik variabel manifest yang berhubungan dengan konstruk laten eksogen $\mathcal{E}$

$\mathrm{Y}=$ Matrik variabel manifest yang berhubungan dengan konstruk laten endogen $\eta$

$\pi_{x}$ dan $\pi_{y}=$ Matriks koefisien (matriks loading)

$\varepsilon_{x} \mathrm{dan} \varepsilon_{y}=$ Matriks outer model residu

\section{a. Convergent Validity}

Menurut (Yamin \& Heri, 2011) mengatakan bahwa convergent validity adalah tingkatan sejauh mana hasil pengukuran suatu konsep menunjukkan korelasi positif dengan hasil pengukuran konsep lain secara teoritis harus berkorelasi positif. Convergent validity besarnya korelasi antara konstrak dengan variabel laten. Dalam melakukan evaluasi convergent validity dapat dilihat dari individual item reliability, dan dari nilai standardized loading factor, pengukuran (indikator) dengan konstruknya. Apabila nilai loading faktor di atas 0,70 maka dikatakan ideal, dan dapat disimpulkan bahwa indikator dinyatakan valid sebagai indikator yang mengukur konstruk. Namun, jika nilai standardized loading factor $\geq$ 0,50 masih dapat diterima, sedangkan $\leq 0.50$ maka akan dikeluarkan dari model (Yamin \& Heri, 2011)

\section{b. Discriminant Validity}

Menurut Yamin \& Heri (2011) discriminant validity dari model reflektif dievaluasi melalui cros loading, kemudian membandingkan nilai AVE dengan kuadrat nilai korelasi antar konstruk (atau membandingkan akar AVE dengan korelasi antar konstrak). Ukuran cross loading merupakan perbandingan antara korelasi indikator dengan konstraknya dan konstrak dari blok lainnya. Jika nilai indikator dengan konstrak lebih tinggi dari korelasi 
dengan blok lainnya, maka hal ini menunjukkan konstrak tersebut memprediksi ukuran pada blok mereka dengan lebih baik dari blok lainnya. Ukuran discriminant validity lainnya adalah akar AVE harus lebih tinggi dari pada korelasi antara konstrak dengan konstrak lainnya atau nilai AVE lebih tinggi dari kuadrat korelasi antar konstrak.

\section{c. Composite Reliability}

Menurut Ghozali (2015) composite reliability dilakukan dengan melihat review latent variable coefficients. Dari output tersebut, maka kriteria dilihat dari dua hal yaitu composite reliability dan cronbach's alpha. Dapat dikatakan reliabel apabila nilai dari uji keduanya di atas 0,70. Dengan demikian, apabila suatu konstruk telah memenuhi dua kriteria tersebut maka dapat dikatakan reliabel. Adapun, pendapat lain yang dinyatakan oleh Yamin \& Heri (2011) mengatakan bahwa cronbach's alpha dalam PLS dikatakan baik apabila di atas 0,5 dan dikatakan cukup apabila di atas 0,3. Jika konstruk telah memenuhi kedua syarat tersebut maka dapat disimpulkan bahwa konstruk reliabel.

\section{Evaluasi Model Struktural (Inner Model)}

Inner model digunakan untuk menentukan spesifikasi hubungan antara konstrak laten dan konstrak lainnya. Persamaan dari inner model adalah sebagai berikut Yamin \& Heri, (2011)

$$
\eta=\eta \beta+\varepsilon \mathrm{T}+\varepsilon
$$

Keterangan:

$\eta=$ Matriks konstrak laten endogen

$\varepsilon=$ Matriks konstrak laten eksogen

$\beta=$ Koefisien matriks variabel endogen

$\mathrm{T}=$ Koefisien matriks variabel eksogen

$\mathrm{E}=$ Inner model residual matriks

\section{a. Uji Model Fit}

Evaluasi model struktural (inner model) meliputi uji kecocokan model (model fit), path coefficient, dan $\mathrm{R}^{2}$. Uji model fit ini digunakan untuk mengetahui apakah suatu model memiliki kecocokan dengan data. Pada uji kecocokan model terdapat 3 indeks pengujian, yaitu average path coefficient (APC), average $R$-squared (ARS), dan average variants factor (AVIF). Nilai p untuk APC dan ARS harus lebih kecil dari 0,05 yang dapat dikatakan signifikan. Selain itu nilai AFIV sebagai indikator multikolinearitas harus lebih kecil dari 5 (Ghozali, 2015). 


\section{b. Uji Hipotesis}

Dalam melakukan uji hipotesis digunakan untuk menjelaskan arah hubungan antara variabel independen dan variabel dependen. Pengujian ini dilakukan dengan cara analisis jalur (path analysis) atas model yang telah dibuat. Program WarpPLS 6.0 dapat secara simultan menguji model struktural yang komplek, sehingga dapat diketahui hasil analisis jalur dalam satu kali analisis regresi. Tingkat signifikansi yang digunakan dalam penelitian ini yaitu sebesar $5 \%$ jika nilai $p$-value $\geq 0,05$ maka hipotesis ditolak dan jika nila $p$-value $\leq$ 0,05 maka hipotesis diterima.

\section{HASIL DAN PEMBAHASAN}

\section{Evaluasi Model Struktural (Outer Model)}

Outer model dilihat dari composite reliability, crobach alpha, dan average variance extracted. Output evaluasi outer model yang dihitung dengan WarpPLS 6.0 dapat dilihat di tabel 2.

Tabel 2. Hasil Output Evaluasi Outer Model

\begin{tabular}{|c|c|c|c|c|c|}
\hline & $\begin{array}{c}\text { Composite } \\
\text { Reliability }\end{array}$ & $\begin{array}{c}\text { Cronbach's } \\
\text { alpha }\end{array}$ & $\begin{array}{c}\text { Average } \\
\text { Variance } \\
\text { Extracted }\end{array}$ & Validitas & Reliabilitas \\
\hline $\mathrm{X} 1$ & 0.813 & 0.541 & 0.685 & Valid & Reliabel \\
\hline $\mathrm{X} 2$ & 1.000 & 1.000 & 1.000 & Valid & Reliabel \\
\hline $\mathrm{X} 3$ & 1.000 & 1.000 & 1.000 & Valid & Reliabel \\
\hline $\mathrm{X} 4$ & 1.000 & 1.000 & 1.000 & Valid & Reliabel \\
\hline $\mathrm{X} 5$ & 0.790 & 0.468 & 0.653 & Valid & Reliabel \\
\hline $\mathrm{Y}$ & 1.000 & 1.000 & 1.000 & Valid & Reliabel \\
\hline $\mathrm{Z}$ & 1.000 & 1.000 & 1.000 & Valid & Reliabel \\
\hline $\mathrm{Z} * \mathrm{X} 1$ & 0.837 & 0.610 & 0.719 & Valid & Reliabel \\
\hline $\mathrm{Z} * \mathrm{X} 2$ & 1.000 & 1.000 & 1.000 & Valid & Reliabel \\
\hline $\mathrm{Z} * \mathrm{X} 3$ & 1.000 & 1.000 & 1.000 & Valid & Reliabel \\
\hline $\mathrm{Z}$ X4 & 1.000 & 1.000 & 1.000 & Valid & Reliabel \\
\hline $\mathrm{Z} * \mathrm{X} 5$ & 0.797 & 0.491 & 0.662 & Valid & Reliabel \\
\hline
\end{tabular}

Sumber : Data diolah WarpPLS 6.0 (2019)

\section{Evaluasi Model Struktural (Inner Model)}

Uji kecocokan model (model fit) ini digunakan untuk mengetahui apakah suatu model memiliki kecocokan dengan data disajikan pada tabel 3. 
Tabel 3. Model fit

\begin{tabular}{|c|c|c|c|}
\hline & Indeks & p-value & Keterangan \\
\hline APC & 0.183 & 0.025 & Diterima \\
\hline ARS & 0.573 & $<0.001$ & Diterima \\
\hline AVIF & 1.253 & $<5.00$ & Diterima \\
\hline$R^{2}$ & 0.505 & $<0.001$ & Diterima \\
\hline
\end{tabular}

Sumber : Data diolah WarpPLS 6.0 (2019)

Model struktural penelitian disajikan dalam gambar 3.

Gambar 3. Model Penelitian

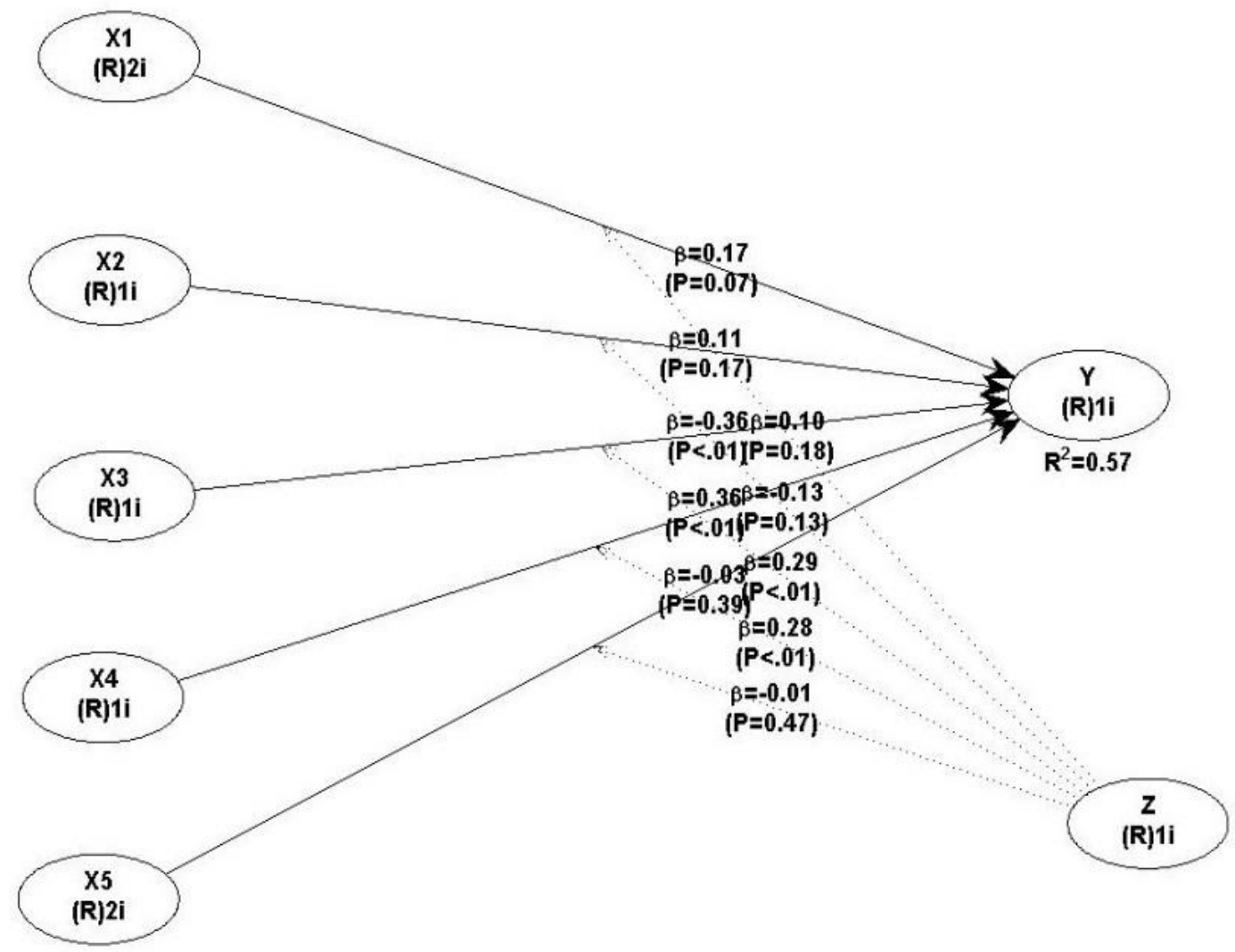

Sumber : Data diolah WarpPLS 6.0 (2019)

\section{Pengujian Koefisien Determinasi ( $R$ Square)}

Pada uji $R$ Square diperoleh nilai sebesar 0.505 atau $50.5 \%$ dari variabilitas konstruk Cash Holding dapat dijelaskan oleh kelima variabel laten endogen yaitu Sedangkan sisanya sebesar $49.5 \%$ dijelaskan oleh variabel lain diluar model penelitian. 
Tabel 4. Model fit indices

\begin{tabular}{|c|c|c|c|}
\hline & Path Coefficient & P Values & Keterangan \\
\hline $\mathrm{X} 1$-> Y & 0.166 & 0.068 & Ditolak \\
\hline $\mathrm{X} 2$-> Y & 0.109 & 0.167 & Ditolak \\
\hline $\mathrm{X} 3$-> Y & -0.361 & $<0.001$ & Diterima \\
\hline $\mathrm{X} 4$-> Y & 0.359 & $<0.001$ & Diterima \\
\hline $\mathrm{X} 5$-> Y & -0.032 & 0.392 & Ditolak \\
\hline $\mathrm{Z} * \mathrm{X} 1$-> Y & 0.102 & 0.185 & Ditolak \\
\hline $\mathrm{Z} * \mathrm{X} 2$-> Y & -0.128 & 0.129 & Ditolak \\
\hline $\mathrm{Z} * \mathrm{X} 3$-> Y & 0.289 & 0.004 & Diterima \\
\hline $\mathrm{Z} * \mathrm{X} 4->\mathrm{Y}$ & 0.282 & 0.005 & Diterima \\
\hline $\mathrm{Z} * \mathrm{X} 5$-> Y & -0.007 & 0.474 & Ditolak \\
\hline
\end{tabular}

Sumber : Data diolah, output WarpPLS 6.0 (dengan nilai sig 5\%) (2019)

\section{Pembahasan}

Net working capital bernilai positif, tetapi tidak signifikan terhadap cash holding. Dapat diartikan bahwa semakin tinggi net working capital tidak mempengaruhi perusahaan untuk menahan kas. Hal ini dapat mengindikasi bahwa apabila perusahaan memiliki net working capital yang tinggi, maka kas yang ada dalam perusahaan tersebut tidak likuid dan lebih cenderung untuk mengalami kebangkrutan. Penelitian ini mendukung penelitian Maarif, Anwar, \& Darmansyah (2019) dan Khalil \& Mukhtiar (2017) yang menunjukkan bahwa terdapat hubungan negatif dan tidak signifikan antara net working capital terhadap cash holding. Namun, hal ini tidak sesuai dengan penelitian Senjaya \& Yadnyana (2016) dan Wulandari \& Setiawan (2019) yang mengatakan bahwa net working capital berpengaruh dan signifikan terhadap cash holding.

Capital expenditure bernilai positif, tetapi tidak signifikan terhadap cash holding. Perusahaan industri barang konsumsi yang memiliki capital expenditure tinggi tidak mempengaruhi aktivitas manajemen dalam menahan kas (cash holding). Ketika capital expenditure yang dimiliki oleh perusahaan besar, maka dapat membeli aset tetap yang cukup banyak pula. Dengan demikian, hasil aset tetap yang telah dibeli oleh perusahaan dapat meningkatkan cash holding. Penelitian ini sejalan dengan Ariana, Hadjaat, \& Yudaruddin (2018) dan Maarif, Anwar, \& Darmansyah (2019) yang menunjukkan bahwa capital expenditure tidak berpengaruh signifikan terhadap cash holding. Akan tetapi, penelitian ini bertentangan dengan penelitian Hadiwijaya \& Trisnawati (2019) hasilnya menunjukkan terdapat pengaruh positif antara belanja modal terhadap cash holding. 
Cash conversion cycle berpengaruh negatif terhadap cash holding dan signifikan. Apabila siklus konversi kas yang berlangsung pada perusahaan memakan waktu yang lama menunjukkan bahwa semakin lama pula kas yang terkumpul atas penjualan produk yang telah dilakukan oleh perusahaan.Oleh karena itu, kebutuhan akan pendanaan internal perusahaan untuk membiayai operasional perusahaan semakin besar yang menyebabkan perusahaan akan lebih banyak menahan kas (cash holding). Hasil penelitian ini mendukung Humendru \& Pangaribuan (2018) yang menyatakan bahwa cash conversion cycle berpengaruh positif signifikan terhadap cash holding. Namun, hasil penelitian ini tidak sejalan dengan penelitian Senjaya \& Yadnyana (2016) yang mengatakan bahwa cash conversion cycle tidak memiliki pengaruh terhadap jumlah cash holding.

Cash flow berpengaruh positif terhadap cash holding dan signifikan. Ketika arus kas bernilai positif maka semakin besar pula perusahaan untuk menahan kas lebih banyak. Hal ini disebabkan dengan banyaknya menahan kas nantinya akan digunakan untuk membiayai operasional perusahaan. Hasil penelitian ini mendukung penelitian Tayem (2017) dan Hadiwijaya \& Trisnawati (2019) yang mengatakan arus kas berpengaruh positif dan signifikan terhadap cash holding. Namun tidak sejalan dengan penelitian Trinh \& Thuy Mai (2016) yang mengatakan arus kas tidak berpengaruh signifikan terhadap cash holding.

Growth opportunity bernilai positif terhadap cash holding, tetapi tidak signifikan. Besar atau kecilnya growth opportunity pada perusahaan belum cukup untuk menentukan apakah perusahaan akan melakukan untuk menahan kas dalam jumlah yang besar. Hal ini dikarenakan, perusahaan tidak terlalu mempertimbangkan dengan memiliki tingkat growth opportunity yang tinggi akan melakukan penahanan kas yang tinggi pula. Hasil penelitian ini mendukung penelitian Humendru \& Pangaribuan (2018) dan Wulandari \& Setiawan (2019) yang mengatakan growth opportunity tidak berpengaruh dan tidak signifikan terhadap cash holding. Namun, tidak sejalan dengan penelitian yang dilakukan William \& Fauzi (2013) dan Tayem (2017) yang menyatakan bahwa growth opportunity berpengaruh signifikan terhadap cash holding.

Pengaruh aktivitas dewan komisaris tidak dapat memoderasi antara net working capital terhadap cash holding. Hal ini dikarenakan dalam sebuah perusahaan rapat dewan komisaris yang telah dilakukan hanya sebatas menjalankan tugas dan komite audit, dilaksanakan setiap saat bila diperlukan. Penelitian ini sejalan dengan penelitian Maarif, Anwar, \& Darmansyah (2019) menunjukkan bahwa hubungan antara aktivitas dewan komisaris terhadap cash holding yang dimoderasi oleh aktivitas dewan komisaris tidak signifikan. 
Aktivitas dewan komisaris tidak dapat memoderasi antara capital expenditure terhadap cash holding. Peran kontrol dewan komisaris tidak berhubungan terhadap belanja modal. Ketika capial expenditure cukup tinggi, maka perusahaan akan membeli aset tetap yang cukup banyak yang membuat dewan komisaris mendukung atas ketersediaan dalam pembelian aset tetap dan tidak melakukan penahanan kas. Hal ini menyebabkan aset tetap tersebut dapat menguntungkan perusahaan untuk meningkatkan kas. Penelitian sejalan dengan Ariana, Hadjaat, \& Yudaruddin (2018) yang mengatakan bahwa capital expenditure tidak berpengaruh signifikan terhadap cash holding. Namun, tidak sejalan dengan penelitian yang dilakukan oleh Maarif, Anwar, \& Darmansyah (2019) yang menyatakan bahwa aktivitas dewan komisaris memoderasi hubungan antara capital expenditure terhadap cash holding diperkuat oleh aktivitas dewan komisaris.

Aktivitas dewan komisaris dapat memoderasi antara cash conversion cycle terhadap cash holding. Ketika perusahaan sering melaksanakan rapat dewan komisaris, maka dapat sebagai kontrol serta evaluasi sehingga cash conversion cycle tidak terlalu panjang. Hal ini menyebabkan uang kas masuk dalam perusahaan cepat sehingga perusahaan tidak perlu melakukan penahanan kas untuk pembiayaan bahan baku. Penelitian ini mendukung penelitian yang dilakukan oleh Gill \& Biger (2013) dan Ajanthan \& Kumara (2017) corporate governance mempengaruhi siklus konversi kas. Namun, tidak sejalan dengan Sadono (2016) yang mengatakan bahwa corporate governance tidak berpengaruh dan tidak signifikan terhadap siklus konversi kas (cash conversion cycle).

Aktivitas dewan komisaris dapat memoderasi antara cash flow terhadap cash holding. Semakin baik tata kelola perusahaan, maka dapat meningkatkan kinerja perusahaan yang akan mempengaruhi pada cash flow, dimana arus kas yang masuk pada perusahaan lebih besar dibandingkan dengan arus kas yang keluar. Hasil penelitian mendukung penelitian Hadiwijaya \& Trisnawati (2019) operating cash flow berpengaruh signifikan dan arahnya positif terhadap cash holding. Namun, hasil penelitian ini tidak didukung oleh Ariana, Hadjaat, \& Yudaruddin (2018) mengatakan bahwa operating cash flow tidak berpengaruh dan tidak signifikan arahnya positif terhadap cash holding.

Aktivitas dewan komisaris tidak dapat memoderasi antara growth opportunity terhadap cash holding. Rapat yang dilakukan oleh dewan komisaris pada perusahaan dilakukan hanya sebatas menjalankan tugas serta dilakukannya rapat setiap saat diperlukan. Oleh karena itu, kontrol yang dilakukan oleh dewan komisaris sangat lemah. Besar atau kecilnya growth opportunity pada perusahaan belum cukup untuk menentukan apakah perusahaan akan 
melakukan untuk menahan kas dalam jumlah yang besar. Hasil penelitian ini mendukung penelitian Humendru \& Pangaribuan (2018) dan Wulandari \& Setiawan (2019) yang mengatakan growth opportunity tidak berpengaruh dan tidak signifikan terhadap cash holding. Akan tetapi, tidak sejalan dengan penelitian Saragih (2018) para investor akan lebih merasa aman ketika perusahaan menerapkan corporate goveranance yang baik maka akan memberikan nilai tambah bagi perusahaan terhadap investor. Hal ini dikarenakan corporate governance memberikan pandangan terhadap investor bahwasanya perusahaan telah dikelola dengan baik.

\section{E. KESIMPULAN}

\section{Kesimpulan}

Hasil penelitian pengaruh net working capital, capital expenditure, cash conversion cycle, cash flow, dan growth opportunity dengan aktivitas dewan komisaris sebagai variabel moderasi, membuktikan bahwa pentingnya suatu perusahaan dalam mengelola kas. Variabel yang dapat mempengaruhi cash holding yaitu cash conversion cycle dan cash flow sehingga kebijakan dan motif perusahaan melakukan penahanan kas yaitu berdasar pada motif transaksi dan motif berjaga-jaga. Dengan melakukan hal tersebut diharapkan dapat melindungi kas di masa depan dan tidak terjadi likuidasi pada perusahaan.

\section{Keterbatasan Penelitian}

Penelitian yang telah dilakukan masih terdapat keterbatasan. Pertama, penelitian ini menggunakan analisis regresi linear berganda, sehingga dari sampel yang digunakan yang awalnya 48 perusahaan. Namun setelah dimasukan pada kriteria purposive sampling hanya 30 perusahaan yang menjadi sampel. Kedua, variabel capital expenditure, cash flow, dan corporate governance sebelumnya menggunakan beberapa indikator. Namun, setelah diolah menggunakan software WarpPLS 6.0 hasil output tidak layak digunakan, sehingga indikator pada variabel tersebut dikeluarkan.

\section{Agenda Penelitian yang Akan Datang}

Berdasarkan keterbatasan penelitian yang telah diuraikan, maka terdapat beberapa saran untuk penelitian yang akan datang. Penelitian yang akan datang sebaiknya menggunakan model lain, selain regresi linear berganda, seperti regresi nonlinier, regresi dummy, atau regresi logistik. Selain itu, penelitian selanjutnya disarankan menggunakan indikator yang lebih tepat yang dapat digunakan pada variabel capital expenditure, cash flow, dan corporate governance 


\section{DAFTAR PUSTAKA}

Abdurrahman, A. Z., R, E. N., \& Taqwa, S. (2019). Pengaruh Kepemilikan Institusional, Likuiditas, Dan Pertumbuhan Perusahaan Terhadap Kebijakan Utang (Studi Pada Perusahaan Pertambangan Yang Terdaftar di BEI Tahun 2015-2017). Jurnal Eksplorasi Akuntansi, 1(2), 589-604.

Abor, J. \& Bokpin, G. A. (2010). Investment opportunities, corporate finance, and dividend payout policy Evidence from emerging markets. Studies in Economics and Finance, 27(3), 180-194.

Afif, S., \& Prasetiono. (2016). Analisis Fakor-Faktor yang Mempengaruhi Kebijakan Cash Holding pada Perusahaan Manufaktur yang Listing di Bursa Efek Indonesia Tahun 2010-2014. Diponegoro Journal of Management, 5(4), 1-11.

Ajanthan, A., \& Kumara, K. U. (2017). Corporate Governance and Cash Conversion Cycle: Evidence from Listed Companies in Srilanka. Asian Economic and Financial Review, 7(12), 1303-1316.

Akhtar, T., dkk. (2018). Corporate governance and cash holdings: the way forward. JEL classification-G30, G15, G34, 10(2), 152-170.

Anjum, S. \& Malik, Q. A. (2013). Determinants of Corporate Liquidity -An Analysis of Cash Holdings. IOSR Journal of Business and Management (IOSR-JBM), 7(2), 94-100.

Ariana, D., Hadjaat, M., \& Yudaruddin, R. (2018). Pengaruh Cash Flow, Expenditure dan Nilai Perusahaan terhadap Cash Holding pada Perusahaan Sektor Pertambangan yang Terdaftar di Bursa Efek Indonesia periode 2012-2015. Jurnal Manajemen, 10(1), 7-13.

Bates, T. W., Kahle, K. M., \& Stulz, R. E. (2009). Why Do U.S. Firms Hold So Much More Cash than They Used To?. The Journal of Finance, 64(5), 1985-2021.

Boriçi, A., \& Kruja, A. (2016). Determinants of Firm's Cash Holding Evidence from Shkodra Region, Albania. International Journal of Economics, Commerce and Management, 4(4), 41-52.

Brigham, E. F., \& Houston, J. F. (2011). Dasar-dasar Manajemen Keuangan, 1(Ed.11). Jakarta: Salemba Empat.

Burhanuddin, \& Yusuf, D. (2019). Pengaruh Struktur Modal dan Growth Opportunity terhadap Nilai Perusahaan. Jurnal Sinar Manajemen, 6(1), 1-11.

cnbcindonesia.com. Retrieved from 2019:

https://www.cnbcindonesia.com/market/20190612185652-17-77993/status-pkpuberakhir-tps-food-akhirnya-bebas-dari-pailit. (2019, Juni 12)

cnnindonesia.com. Retrieved from https://www.cnnindonesia.com/ekonomi/20180712183041-92-313651/terancam-pailitbursa-efek-panggil-manajemen-tiga-pilar. (2018, Juli 13)

Das, D. (2017). Effects of Cash Holding on Corporate Performance and Value: Evidence from Indian Companies. Isbr Management Journal, 2(1), 82-88.

Dogru, T. \& Turk, E. S. (2018). Cash Holdings and Corporate Governance: Theory And Contrary Evidence From Hotel Firms. International Journal of Contemporary Hospitality Management, 30(10), 3117-3134. 
Ghozali, I. (2011). Struktural Equation Modeling Metode Alternatif Dengan Partial Least Square (PLS). Semarang: Badan Penerbit Undip.

Ghozali, I., \& Latan, H. (2015). Partial Least Squares (Konsep, Metode, dan Aplikasi) Menggunakan Program WarpPLS 5.0. Semarang: Badan Penerbit Undip.

Gill, A. S., \& Biger , N. (2013). The Impact Of Corporate Governance On Working Capital Management Efficiency Of American Manufacturing Firms. Managerial Finance, 39 (2), 116-132.

Gill, A., \& Shah, C. (2012, January). Determinants of Corporate Cash Holdings: Evidence from Canada. International Journal of Economics and Finance, Vol. 4(1).

Guizani, M. (2017). The financial determinants of corporate cash holdings in an oil rich country: Evidence from Kingdom of Saudi Arabia. Borsa Istanbul Review, 17(4), 133143.

Hadiwijaya, I., \& Trisnawati, E. (2019). Pengaruh Arus Kas Dan Belanja Modal Terhadap Cash Holding Pada Perusahaan Manufaktur. Jurnal Multiparadigma Akuntansi, I (2), 416-424.

Horne, V., \& Wachowicz, M. (2013). Prinsip-prinsip Manajemen Keuangan (Edisi ke 13 ed.). Jakarta: Salemba Empat.

Humendru, A., \& Pangaribuan, J. (2018). Faktor-faktor yang Mempengaruhi Kebijakan Cash Holding (Studi Kasus pada Perusahaan Manufaktur yang terdaftar di Bursa Efek Indonesia Tahun 2012-2015). Jurnal Riset Akuntansi \& Keuangan, 4(1) 1-22.

Husnan, S., \& Pudjiastuti, E. (2015). Dasar-dasar Manajemen Keuangan. Yogyakarta: Unit Penerbit dan Percetakan.

Indonesia, P. U. G. C. G. (2006). Komite Nasional Kebijakan Governance.

Islam, S. (2012). Manufacturing Firm's Cash Holding Determinants: Evidence from Bangladesh. International Journal of Business and Management, 7(6), 172-184.

Khalil , M. S., \& Mukhtiar, K. (2017). Determinants of Cash Holding in Pakistan: a Case of Oil and Gas Sector of Pakistan Stock Exchange. City University Research Journal,7(2), 167-177.

Liestyasih, L. E., \& Wiagustini, L. P. (2017). Pengaruh Firm Size dan Growth Opportunity terhadap Cash Holding dan Firm Value. Jurnal Ekonomi dan Bisnis Universitas Udayana, 6(10), 3607-3636.

Lilia, W., Sitorus, W. S., \& Br. Tarigan, P. R. (2019). Pengaruh Operating Cash Flow (Arus Kas Operasi), Debt to Equity Ratio, Current Ratio (CR), Total Asset Turn Over (TATO) terhadap Profitabilitas pada Sektor Industri Barang Konsumsi yang terdaftar di Bursa Efek Indonesia (BEI) Periode 2014-2017. Jurnal Aksara Public, 3(2), 181-190.

M, B., \& Vidal, S. (2010). Cash holdings in Private Firms. Journal of Banking \& FInance, 36(1), 26-35.

Maarif, S., Anwar, C., \& Darmansyah. (2019). Pengaruh Interest Income Growth, Net Working Capital, dan Capital Expenditure terhadap Cash Holding dengan Aktivitas Dewan Komisaris sebagai Variabel moderasi. J. Madani, 2(1), 163-173. 
Mesfin, E. A. (2016). The Factors Affecting Cash Holding Decisions of Manufacturing Share Companies in Ethiopia. International Journal of Advanced Research in Management and Social Sciences, 5(3), 48-67. Retrieved from www.garph.co.uk

Monica, L., Susanti, M., \& Dewi, S. (2019). Faktor Yang Mempengaruhi Cash Holding Perusahaan Manufaktur Di BEI. Jurnal Multiparadigma Akuntansi, 1(3), 827-834.

Muhammad, T. T., \& Rahim, S. (2015). Pengaruh tingkat Likuiditas dan Profitabilitas terhadap Harga Saham pada Perusahaan Manufaktur yang terdaftar di Bursa Efek Indonesia (BEI). Jurnal Akuntansi Aktual, 3(2), 117-126.

Muharromah, N. A., Ahmar, N., \& Anwar, C. (2019). Institutional Ownership Moderasi Growth Opportunity, Cash Conversion Cycle, Net Working Capital dan Dividend Payout terhadap Cash Holding. JIMEA-Jurnal Inovasi Manajemen Ekonomi dan Akuntansi, 1 (2).

Nagar, N., \& Raithatha, M. (2016). Does Good Corporate Governance Constrain Cash Flow Manipulation? Evidence from India. Managerial Finance, 42(11), 1034-1053.

PSAK No. 02 (Revisi 2009) Exposure Draft Pernyataan Standar Akuntansi Keuangan Laporan Arus Kas. (2009). Jakarta: Dewan Standar Akuntansi Keuangan.

Rehman, A. U., \& Wang, M. (2015). Corporate Cash Holdings and Adjustment Behaviour in Chinese Firms: An Empirical Analysis Using Generalized Method of Moments. Australasian Accounting, Business and Finance Journal, 9(4), 20-37.

Romadhoni, R., Kufepaksi, M., \& Hendrawaty, E. (2019). Faktor-Faktor yang Mempengaruhi Cash Holding Perusahaan yang Listing di Bursa Efek Indonesia Tahun 2013-2017. The Manager Review, 1(2), 124-139.

Sadono, M. R. (2016). Pengaruh Proporsi Komisaris Independen, Ukuran Komite Audit dan Ukuran Perusahaan terhadap Siklus Konversi Kas. Akuntabilitas: Jurnal Ilmu Akuntansi, 9 (2), 231 - 242.

Saragih, R. A. (2018). Pengaruh Growth Opportunity, Profitabilitas, dan Struktur Modal terhadap Nilai Perusahaan dengan Good Corporate Governance sebagai Variabel Moderasi pada Perusahaan Manufaktur Sektor Tekstil dan Garmen di Bursa Efek Indonesia Periode 2012-2016, (Ed.1). JOM FEB, 1, 1-14.

Senjaya, S. Y., \& Yadnyana, I. K. (2016). Analisis Pengaruh Investment Opportunity Set, Cash Conversion Cycle dan Corporate Governance Structure terhadap Cash Holdings. Jurnal Ekonomi dan Bisnis Universitas Udayana, 5(8), 2549-2578.

Siddiqua, G. A., Rehman, A. U., \& Hussain, S. (2019). Asymmetric targeting of corporate cash holdings and financial constraints in Pakistani firms. Journal of Asian Business and Economic Studies, 26(1), 76-97.

Stefany, \& Ekadjaja, A. (2019). Faktor Yang Mempengaruhi Cash Holding Perusahaan Yang Terdaftar Di Bursa Efek Indonesia. Jurnal Multiparadigma Akuntansi, I (3), 610-618.

Suherman. (2017). Faktor-Faktor yang Mempengaruhi Cash Holding di Bursa Efek Indonesia. Jurnal Manajemen, 21(3), 336-349. 
Sumartha , M., \& Tjakrawala , F. K. (2020). Pengaruh Leverage, Profitability, dan Growth Opportunities terhadap Cash Holding. Jurnal Multiparadigma Akuntansi Tarumanagara, 2(1), 459 - 468.

Tayem, G. (2017). The Determinants of Corporate Cash Holdings: The Case of a Small Emerging Market. International Journal of Financial Research, 8(1), 143-154.

Telly, B. R., \& Ansori, M. (2017). Pengaruh Ukuran dan Cash Conversion Cycle terhadap Profitabilitas Perusahaan. Journal of Applied Managerial Accounting, 1(2), 179-189.

tribunnews.com. (2018). Retrieved from https://www.tribunnews.com/bisnis/2018/10/18/5fakta-singkat-bangkrutnya-perusahaan-teh-sariwangi-sudah-pinjam-rp-1-triliuninvestasi-gagal

Trinh, T. H., \& Thuy Mai, P. T. (2016). The Determinants of Corporate Liquidity in Real Estate Industry: Evidence from Vietnam. International Journal of Economics and Finance, 8(7), 21-30.

William, \& Fauzi, S. (2013). Analisis Pengaruh Growth Opportunity, Net Working Capital, dan Cash Conversion Cycle terhadap Cash Holdings Perusahaan Sektor Pertambangan. Jurnal Ekonomi dan Keuangan, 1(2), 72-90.

Wulandari, E. A., \& Setiawan, M. A. (2019). Pengaruh Growth Opportunity, Net Working Capital, Cash Conversion Cycle dan Dividend Payout terhadap Cash Holding (Studi Empiris pada Perusahaan Property dan Real Estate yang Terdaftar di Bursa Efek Indonesia Tahun 2014-2017). Jurnal Eksplorasi Akuntansi Seri D, 1(3), 1259-1274.

www.cnbcindonesia.com. (2019, Juni 12). Retrieved from https://www.cnbcindonesia.com/market/20190612185652-17-77993/status-pkpuberakhir-tps-food-akhirnya-bebas-dari-pailit

www.idx.co.id. (2019).

www.liputan6.com. (2018, Oktober 17). Retrieved from https://www.liputan6.com/bisnis/read/3670168/sariwangi-dinyatakan-pailit

Yamin, S. K., \& Heri. (2011). Generasi Baru Mengolah Data Penelitian dengan Partial Least Square Path Modeling. Jakarta: Salemba Infotek.

Yanti, Susanto, L., Wirianta, H., \& Viriany. (Maret, 2019). Corporate Governance, Capital Expenditure Dan Cash Holding. Jurnal Ekonomi Fakultas Ekonomi, Universitas Tarumanagara, Jakarta, 24(1), 1-14 